УДК 676.18

DOI: $10.15587 / 2313-8416.2016 .63098$

\title{
COMPARATIVE PULPING OF SUNFLOWER STALKS
}

\author{
(C) V. Barbash, I. Trembus, S. Alushkin, O. Yashchenko
}

The procedure of holocellulose content determination in non-wood plant raw materials was developed. The strength properties of pulp obtained from sunflower stalks by neutral-sulphite, soda, alkaline sulphiteanthraquinone-ethanol and peracetic methods of delignification were studied. Methodology of comparison of plant materials delignification methods using new lignin-carbohydrate diagram was proposed. It was shown, that the alkaline sulphite-anthraquinone-ethanol method of pulping is characterized by the highest delignification degree and is the most efficient among the studied methods

Keywords: sunflower stalk, holocellulose, delignification, lignin-carbohydrate diagram, delignification degree

Розроблено методику визначення вмісту холоцеллюлози в недеревних рослинній сировині. Вивчено показники якості целюлози, отриманої з стебел соняшнику нейтральним-сульфітним, натронним, лужносульфітно-спиртовим та пероцтовим способами делігніфікації. Запропонована методика порівняння різних методів делігніфікації рослинної сировини з використанням нової лігнін-вуглеводної діаграми. Показано, щуо лужно-сульфітно-спиртовий спосіб варіння целюлози характеризується високим ступенем делигнификації $і$ є найбільи ефективним серед вивчених методів

Ключові слова: стебла соняшнику, холочелюлоза, делігніфікація, лігнін-вуглеводна діаграма,ступінь делігніфікації

\section{Introduction}

Living standards improvement requires increase in quality and quantity of consumer goods, in particular paper and paperboard. To produce them it is necessary to increase the volumes of primary pulps. For the countries with limited free timber resources non-wood plant raw materials are used in order to increase pulp and paper production [1-3]. Non-wood plant raw materials also can be applied as an effective alternative to constantly decreasing forest resources in different regions. In countries with developed agriculture millions tones of by-products suitable for obtaining pulp are produced by cereal and technical crops treatment. Potential world resources of non-wood plant raw materials exceed 2.5 billion tons per year [4] and renew annually. Using non-wood plant raw materials in pulp and paper industry is beneficial in terms of environmental and socio-economic aspects. Wheat [5], rice [6] and canola [7] straw, abaca [8], bagasse [9], corn and reed [10], cotton [11], hemp [12], kenaf [13], miscanthus [14], elephant and switch grass [15], rapeseed straw [16], etc. have become widely spread as the types of non-wood plant raw materials for obtaining pulp. \section{inition}

\section{Analysis of published data and problem def-}

Sunflower is the most popular plant in many countries and is one of the profitable technical crops with high level of cost-effectiveness among agriculture crops. Sunflower is the third most cultivated oil plant in the world [17]. According to the US Department of Agriculture its production will take to 39.8 million ton during the periods of 2013-2014 year, which is relative increase of $9 \%$, compared to last year [18]. Such increase results from the more efficient cropping techniques and increase in overall sunflower plantings.

In worldwide practice of pulp and paper industry the alkaline methods, in particular soda, sulfate and neutral-sulphite processes have become the most common cooking methods of obtaining pulp from lignocellulose materials [19]. Different methods of more ecological organosolv pulping are widely developed and applied [20-22]. Each of these methods has its advantages and disadvantages by physical and mechanical, ecological and economic indices.

Comparison of methods for pulping non-wood plant raw materials, including sunflower stalks, is devoted to number of works $[10,23,24]$ with analysis of yield, kappa number, viscosity, bonding abilities of fibers, physical and mechanical indices of resulting pulps, its characteristics of beating and bleaching, etc. However, lignin-carbohydrate diagrams as well as comparing lignin extraction indices from plant material for additional evaluation of different delignification methods efficiency can be used.

\section{The aim of the study}

Therefore, the aim of this study is to obtain and compare yield, residual lignin content, strength properties of resulting pulps, to determinate delignification degree, construction and analysis of new lignin-carbohydrate diagram for different sunflower stalks delignification methods to determine a more efficient one.

\section{Experimental Sections Materials and methods} 4. 1. Raw materials

Sunflower (Helianthus annuus) stalks of 2012 harvest were taken in Sumy region of Ukraine in late autumn and were used for obtaining pulp. The stalks were cut at $0.1 \mathrm{~m}$ from the ground level and the leaves were trimmed. For the research purpose the stalks were cleaned out of leaves, cut at height of $20 \pm 5 \mathrm{~mm}$ and stored in desiccators to maintain constant humidity and chemical composition. Pith was eliminated because it contributes to various problems during cooking such as requirement of additional consumption of chemicals, increasing the foam, deterioration in the 
quality of pulp and paper [25] and problems related to drainage [26].

Stalks of corn, wheat straw and rapeseed were used in order to perform comparative analysis of chemical composition. Corn (Zea mays) is one-year cereal growing in all regions of the world and has a gross rounded stalk up to $6 \mathrm{~m}$, thickness $2-7 \mathrm{~cm}$ with core, which is filled of parenchyma cells (pith). In this work, the corn stalks from the Cherkassy region of Ukraine were used. For the research purpose the stalks were cleaned out of leaves, cut at height of $20 \pm 5 \mathrm{~mm}$, pith was eliminated and prepared materials stored in desiccators to maintain constant humidity and chemical composition.

Wheat straw (Triticum vulgare) is an annual grass of the cereal family (Gramineae, Poaceae) and is widely used not only for fuel production, but also as feed, livestock bedding, fodder and takes leading position in the processing capacity among non-wood raw materials in pulp and paper industry. Rapeseed (Brassica napus) belongs to herbaceous plants of the family (Brassicáceae). It is extremely important oil plant used mainly for obtaining of biodiesel. For the research the stalks of wheat straw and rapeseed from Vinnitsa region of Ukraine were cleaned out of leaves, cut at height of $20 \pm 5 \mathrm{~mm}$ and stored in desiccators to maintain constant humidity and chemical composition. The moisture content of all lignocelluloses' materials was $7 \pm 1 \%$.

\section{2. Chemical analysis}

Stalks of sunflower, corn, wheat straw and rapeseed were grinded in Wiley mill to produce sawdust on 40/60 mesh, which was analyzed for chemical composition. It was identified according to existing TAPPI standard procedures for different components [27], namely: T 211 om-07 for ash, T 428 om-08 for hot-water extractives, T 212 for $1 \% \mathrm{NaOH}$ soluble substances, T $204 \mathrm{~cm}-$ 07 for alcohol-benzene extractives, T $222 \mathrm{~cm}-01$ for pentosanes, T 222 om-02 for Klason lignin and cellulose by the Kürschner-Hoffer method [28]. All chemical analyses were carried out twice allowing to calculate the mean values and standard deviations, which do not exceed $5 \%$.

Holocellulose content was identified by TAPPI T 203 cm-09 standard procedure with our modification accounting peculiarities of anatomical structure and chemical composition of annual plants. The key point of the modification was 30 minutes treatment of preliminary extracted by alcohol-benzene non-wood samples by $10 \%$ peracetic acid at a temperature of $90{ }^{\circ} \mathrm{C}$. Then the content of flask was diluted by hot water $\left(50-70{ }^{\circ} \mathrm{C}\right)$ in $3-5$ times to decrease acid concentration and stop reaction. After that, mixture was filtered through two paper filters. Holocellulose was first rinsed by hot water to the absence of hydrogen peroxide. Then it was treated with 1:1 alcoholacetone mixture at the room temperature. Drying of holocellulose was carried out in a vacuum oven at a temperature below $60{ }^{\circ} \mathrm{C}$ or in the air to prevent decomposition of hemicelluloses. Holocellulose content in plant raw material was defined by weight method relatively to airdry sample. Obtaining of holocellulose and determination of holocellulose content in plant raw materials is very important. It allows performing of hemicelluloses extraction better from holocellulose than from plant raw mate- rial. The value of the holocellulose content in plant material is also important for constructing new lignincarbohydrate diagram, which will be announced later.

\section{3. Pulping}

Cooking of pulp from sunflower stalks by neutralsulphite (N-Su), soda and alkaline sulphiteanthraquinone-ethanol (ASAE) methods was performed in steel autoclaves of $0.5 \mathrm{dm}^{3}$ capacity placed in glycerin bath heated to set temperature. The autoclaves were cooled after cooking. Obtained pulp was washed from liquor with running water to neutral $\mathrm{pH}$ and dewatered by pressing to dryness about $30 \%$. Pulp yield was determined by gravimetric method after drying at a temperature of $105{ }^{\circ} \mathrm{C}$ during $24 \mathrm{~h}$. Residual lignin content in pulp was determined in relation to absolutely dry raw material (a.d.r.m.) according to existing TAPPI standard procedures [27]. Neutral-sulphite cooking of sunflower stalks was performed by cooking liquor with $\mathrm{SO}_{2}$ concentration $30 \mathrm{~g} / \mathrm{l}$, at a temperature of $175^{\circ} \mathrm{C}$, duration from 30 to 120 minutes, liquid-to-solid ratio $5: 1$, and $\mathrm{pH}=9,2$. Soda cooking was performed with $\mathrm{NaOH}$ consumption $14 \%$ from a.d.r.m. mass, at a temperature of $175^{\circ} \mathrm{C}$, duration from 90 to 180 minutes, liquid-to-solid ratio $-5: 1$. Alkaline sulphite-anthraquinone-ethanol cooking was performed by sodium sulphite solution and sodium hydroxide with ratio 80:20 volume $\%$, their consumption $25 \%$ from a.d.r.m. mass, alcohol to water ratio $35: 65$ volume $\%$, anthraquinone consumption $0.1 \%$ from a.d.r.m. mass. Temperature of delignification was $175{ }^{\circ} \mathrm{C}$, duration 30-120 minutes, liquid-to-solid ratio $-5: 1$. These values of technological characteristics were taken as optimal on basis of previously performed investigations [28]. Cooking by mixture of hydrogen peroxide and acetic acid (peracetic method) was performed in glass flasks with volume $750 \mathrm{ml}$, which were connected with return condensers. Cooking was performed in the water bath by cooking solution with $35 \%$ hydrogen peroxide solution and $30 \%$ acetic acid solution with ratio $1: 1$, at the temperature $90{ }^{\circ} \mathrm{C}$, duration from 30 to 120 minutes. Sodium tungstate was used as catalyst with consumption $2 \%$ from a.d.r.m. mass. Liquid-to-solid ratio was 15:1. These values of technological characteristics were taken as recommended on basis of previously performed investigations [29].

To obtain more precise and acceptable experimental data, the pulping of sunflower stalks was performed twice. After the cooking processes, the obtained pulp was refined, thoroughly washed, screened with a 10-mesh sieve and pulp properties were carefully measured.

\section{4. Hand sheet preparation and testing}

The pulp samples obtained from sunflower stalks were beaten in centrifugal beating apparatus to reach $60 \pm 2{ }^{\circ} \mathrm{SR}$ beating degree, determined by the SchopperRiegler method according to ISO 5267-1 standard. Laboratory hand sheets from obtained pulps with mass of 1 $\mathrm{m}^{2} 65 \pm 1 \mathrm{~g}$ were produced in a Rapid Köthen machine in accordance with relevant ISO standard 5269-2 method. Then their strength properties were evaluated according to TAPPI standard procedures: base weight - by $\mathrm{T} 410$ om-02, breaking length - by T $404 \mathrm{~cm}-92$, burst index - 
by T 403 om-02, tearing index - by T 414 om-04. Samples were stored at the temperature $20{ }^{\circ} \mathrm{C}$ and relative air humidity $65 \%$ during 24 hours before the tests. For every strength property of hand sheets were determined at least 10 times.

\section{Results and Discussion}

5. 1. Chemical composition of annual plants

Chemical composition of sunflower stalks in comparison with the most common representatives of annual plants shows in Table 1.

Table 1

Chemical composition of annual plants, \%

\begin{tabular}{|c|c|c|c|c|c|c|c|c|}
\hline Components & $\begin{array}{l}\text { Sun- } \\
\text { flower }\end{array}$ & Corn & $\begin{array}{l}\text { Wheat } \\
\text { straw }\end{array}$ & $\begin{array}{c}\text { Rape- } \\
\text { seed }\end{array}$ & $\begin{array}{c}\text { Sun- } \\
\text { flower }^{\mathrm{a}}\end{array}$ & Corn $^{a}$ & $\begin{array}{l}\text { Wheat } \\
\text { straw }^{\text {b }}\end{array}$ & $\begin{array}{l}\text { Rape- } \\
\text { seed }^{\text {b }}\end{array}$ \\
\hline Holocellulose & 67,32 & 70,15 & 74,68 & 62.24 & 66,85 & 69,92 & 74,5 & 58,51 \\
\hline Cellulose & 41,83 & 42,64 & 46,27 & 35,63 & 47,80 & 55,70 & - & - \\
\hline Pentosanes & 24,36 & 25,66 & 26,44 & 25,57 & - & - & - & - \\
\hline Lignin & 20,12 & 17,98 & 18,62 & 22,91 & 14,43 & 18,16 & 15,3 & 15,52 \\
\hline \multicolumn{9}{|c|}{ Extractives } \\
\hline Ash & 3,07 & 4,74 & 4,28 & 3,37 & 7,99 & 7,75 & 4,7 & 8,80 \\
\hline Hot water & 5,68 & 14,88 & 10,14 & 11,64 & 24,26 & 16,82 & 13,99 & 13,35 \\
\hline Ethanol-benzene & 2,15 & 3,57 & 5,23 & 4,82 & 7,48 & 8,57 & - & - \\
\hline $1 \% \mathrm{NaOH}$ & 35,57 & 39,62 & 38,48 & 35,61 & 50,05 & 46,43 & 40,59 & 34,9 \\
\hline
\end{tabular}

Notes: ${ }^{a}$-Ates et al [10]; ${ }^{b}-$ Potucek and Milichovsky [16]

According to the date of Table 1, investigated sunflower stalks contain more lignin compared to other represented plants but is close by cellulose and pentosanes content and lesser minerals and water-soluble and alcoholbenzene extractives. Determined chemical composition of sunflower stalks and the most common representatives of agriculture annual plants (wheat straw, corn and rapeseed stalks) is close to found in the literature $[10,16]$. Stalks of sunflower as well as wheat straw, corn and rapeseed have higher ash content than hardwood and softwood, but the content of hot water extractives and content of ethanolbenzene extractives of sunflower stalks are close to hardwood and softwood extractives [19]. However, $1 \% \mathrm{NaOH}$ extractives content of sunflower stalks, wheat straw, corn and rapeseed stalks is almost twice higher than for softwood and hardwood. Therefore, a priori, it can be assumed that at cooking in an alkaline medium pulp yield from annual plant materials will be lower than from wood and the consumption of chemicals will be higher. Nevertheless, sunflower stalks have less lignin and higher pentosanes content in comparison with hardwood and softwood. Thus, it can be propose that by their chemical composition the sunflower stalks are suitable to obtain pulp for paper and board production.

As can be seen from Table 1, holocellulose content in the studied representatives of non-wood plant raw materials is slightly higher than the published data. This difference is caused by using the modified technique for determination of holocellulose in plant material. The essence of the proposed modification is reaching low residual lignin content with minimal polysaccharides loss, hydrolytic and oxidizing degradation of cellulose. This is achieved by reducing the time of processing of non-wood plant raw materials by solution of peracetic acid for 30 minutes and shows the following results. Results of studies to determine the residual lignin and holocellulose content in sunflower stalks and other crops (wheat straw corn and rapeseed stalks) depending on the time of plant treatment with peracetic acid solutions shown in Figs. 1, 2.

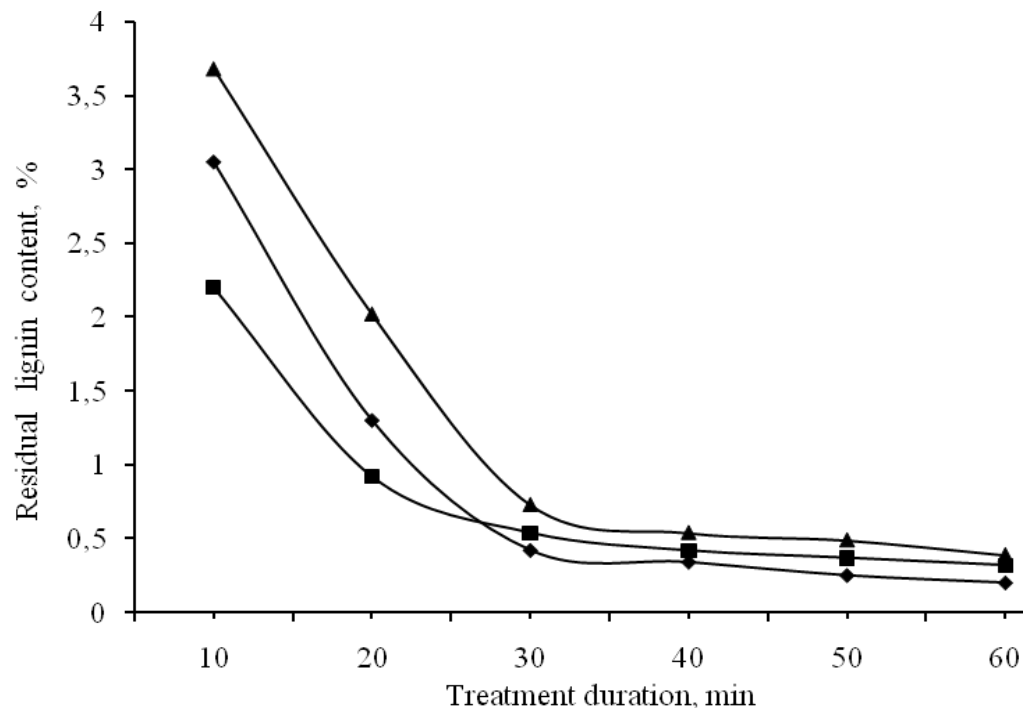

Fig. 1. Dependence of residual lignin content on treatment time of peracetic acid for non-wood plant materials: sunflower $(\boldsymbol{\Delta})$, wheat straw $(\bullet)$ and corn 


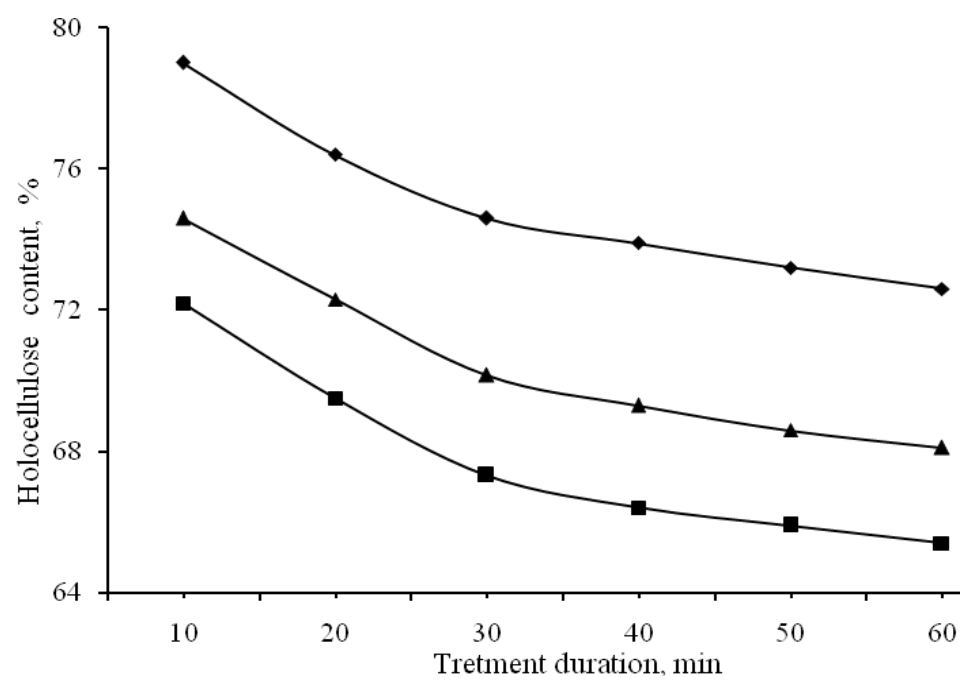

Fig. 2. Dependence of holocellulose content on treatment time of peracetic acid for non-wood plant materials: wheat straw $(\bullet)$, corn $(\boldsymbol{\Delta})$ and sunflower $(\mathbf{\square})$

It is seen from Fig. 1 the residual lignin content in non-wood materials sharply decreases after first 30 minutes of treatment with peracetic acid and then decreases slowly. After 30 minutes treatment of annual plants, residual lignin content remains almost constant, when the holocellulose content continues decreases (Fig. 2). Intensive reduction of holocellulose content is caused by the dominance of polysaccharides cellulose hydrolysis and insignificant removal of the residual lignin from the plant material. Also, another criterion of sufficient treatment was holocellulose color change. After the series of experiments with the different non-wood samples, it was found that holocellulose changes its color from yellow to white after the 30 minutes of treatment with peracetic acid. This proves almost complete absence of lignin in holocellulose and, more precisely, absence of chromophoric groups (carbonyl and carboxyl groups, aromatic rings), contained in lignin and other extractive substances. This is a reason why a further treatment of plant raw material over 30 minutes leads to holocellulose hydrolysis and decreases of its proper value.

Thus, value of holocellulose content in sunflower stalks is $67.32 \%$ from a.d.r.m., which is close to value in literature $66.85 \%$ and was calculated for total sum of $100 \%$ [16]. Value of holocellulose content in sunflower stalks as well as in others annual plants (wheat straw, corn and rapeseed stalks) slightly more than values determined by Wise's method [10].

Advantages of this method of determining holocellulose content in non-wood plant material by solution of peracetic acid is ecologically safer compared to chlorination method. It is based on alternating treatments of deresined raw materials in the presence of water and a solution of organic base in an organic solvent, and also requires lesser duration of experiment and less danger of explosion, than at chlorite (Wise's) method.

\section{2. Pulp properties}

To obtain strength properties of pulp from sunflower stalks, series of cooking by neutral-sulphite, soda, and alkaline sulphite-anthraquinone-ethanol and peracetic delignification methods was carried out. Dependen- cies of yield, residual lignin, physical and mechanical characteristics of resulting pulps on cooking time are demonstrated in Table 2.

It has been observed that increase in cooking time logically decreases pulp yield and residual lignin content for all studied delignification methods. It should be mentioned that the least residual lignin content at the equal yield is observed for ASAE pulp. It can be explained by the fact that during alkaline-organosolv cooking lignin destruction is carried out with breaking of $\alpha$ - and $\beta$-ether bonds through intermediate quinonemethyd structure, which is blocked by organic solvent and prevents lignin condensation. Alcohol alkylation of hydroxyl groups in $\alpha$-position facilitates lignin fragmentation by improving its solubility in organic solvent.

The strength properties of obtained pulps are increasing with the increase of cooking time, which is explained by better papermaking properties of pulp due to additional removing of lignin and extractives and formation of new hydrogen bonds between molecules of cellulose and hemicelluloses. It should be noted that the best strength properties are observed in ASAE pulp in comparison with another studied methods obtaining pulps. It is caused by better protection of pro-xylane against destruction during organosolv cooking allowing it to form stronger matrix in cellulose and, consequently, improve physical and mechanical properties (especially tearing index).

The diagram presented in Fig. 3 confirms such comparative dependence of strength properties of pulps obtained from sunflower stalks by researched delignification methods. The proposed methodology for constructing diagram differs from the known lignin-carbohydrate diagrams Ross, Geertz and Schmidt simplicity of construction, the essence of which is consists of the following.

On the y-axis the pulp yield is indicated from $30 \%$ (for better visualization on the few percent lesser than cellulose content is in the plant raw material) to $100 \%$. On the $y$-axis the point corresponding to holocellulose content is also indicated. On the $\mathrm{x}$-axis the percentage value of the lignin content in pulp is indicated from zero to maximum value in plant raw material (for example, $20 \%$ for sunflower stalks). The intersection of horizontal axis at 
$100 \%$ yield and vertical axis of lignin content creates the point corresponding to initial composition of all plant components (cellulose, hemicelluloses, lignin, resins, fats, and waxes, mineral and others extractive substances). The line, which links this point with the point of holocellulose content in plant raw material, can be considered as the line of "ideal delignification". It characterizes maximal polysac- charide content for certain residual lignin content in pulp. Further on lignin-carbohydrate diagram are applied dependences yield on residual lignin content in the pulps obtained by different methods. So the closer the line of certain delignification method is to the line of "ideal delignification", the higher is polysaccharide yield in the obtained pulp and thus delignification method is more efficient.

Table 2

Parameters of cooking and strength properties of pulps from sunflower stalks obtained by different methods of delignification

\begin{tabular}{|c|c|c|c|c|c|c|}
\hline $\begin{array}{c}\text { Delignification method } \\
\left.\text { (Temperature, }{ }^{\circ} \mathrm{C}\right)\end{array}$ & $\begin{array}{c}\text { Cooking time, } \\
\text { min }\end{array}$ & $\begin{array}{l}\text { Yield of } \\
\text { pulp, \% }\end{array}$ & $\begin{array}{l}\text { Residual } \\
\text { lignin, \% }\end{array}$ & $\begin{array}{l}\text { Brea-king } \\
\text { length, m }\end{array}$ & $\begin{array}{c}\text { Burst index, } \\
\mathrm{kN} / \mathrm{g}\end{array}$ & $\begin{array}{l}\text { Tear index, } \\
\mathrm{mN} \cdot \mathrm{m}^{2} / \mathrm{g}\end{array}$ \\
\hline \multirow{4}{*}{$\begin{array}{l}\mathrm{N}-\mathrm{Su} \\
(175)\end{array}$} & 30 & 55,8 & 8,2 & 3580 & 2,3 & 1,3 \\
\hline & 60 & 51,7 & 6,9 & 4600 & 3,1 & 1,5 \\
\hline & 90 & 47,9 & 6,4 & 5160 & 4,4 & 2,5 \\
\hline & 120 & 47,1 & 5,9 & 5250 & 5,3 & 2,7 \\
\hline \multirow{4}{*}{$\begin{array}{l}\text { Soda } \\
(175)\end{array}$} & 90 & 55,9 & 11,9 & 2890 & 2,4 & 1,0 \\
\hline & 120 & 52,5 & 9,6 & 3450 & 2,7 & 1,2 \\
\hline & 150 & 50,9 & 9,3 & 3620 & 3,0 & 1,3 \\
\hline & 180 & 49,6 & 8,4 & 3910 & 3,1 & 1,4 \\
\hline \multirow{4}{*}{$\begin{array}{l}\text { ASAE } \\
(175)\end{array}$} & 30 & 58,1 & 3,1 & 4750 & 4,5 & 5,4 \\
\hline & 60 & 51,9 & 2,5 & 6350 & 4,8 & 5,7 \\
\hline & 90 & 48,1 & 1,6 & 6850 & 5,7 & 5,9 \\
\hline & 120 & 46,9 & 1,2 & 7500 & 6,3 & 7,1 \\
\hline \multirow{4}{*}{$\begin{array}{l}\text { Peracetic } \\
\quad(90)\end{array}$} & 30 & 57,5 & 7,7 & 3640 & 1,8 & 1,0 \\
\hline & 60 & 47,9 & 6,4 & 4530 & 1,9 & 2,4 \\
\hline & 90 & 42,8 & 4,6 & 4740 & 2,1 & 2,5 \\
\hline & 120 & 40,2 & 3,4 & 5130 & 2,4 & 3,0 \\
\hline
\end{tabular}

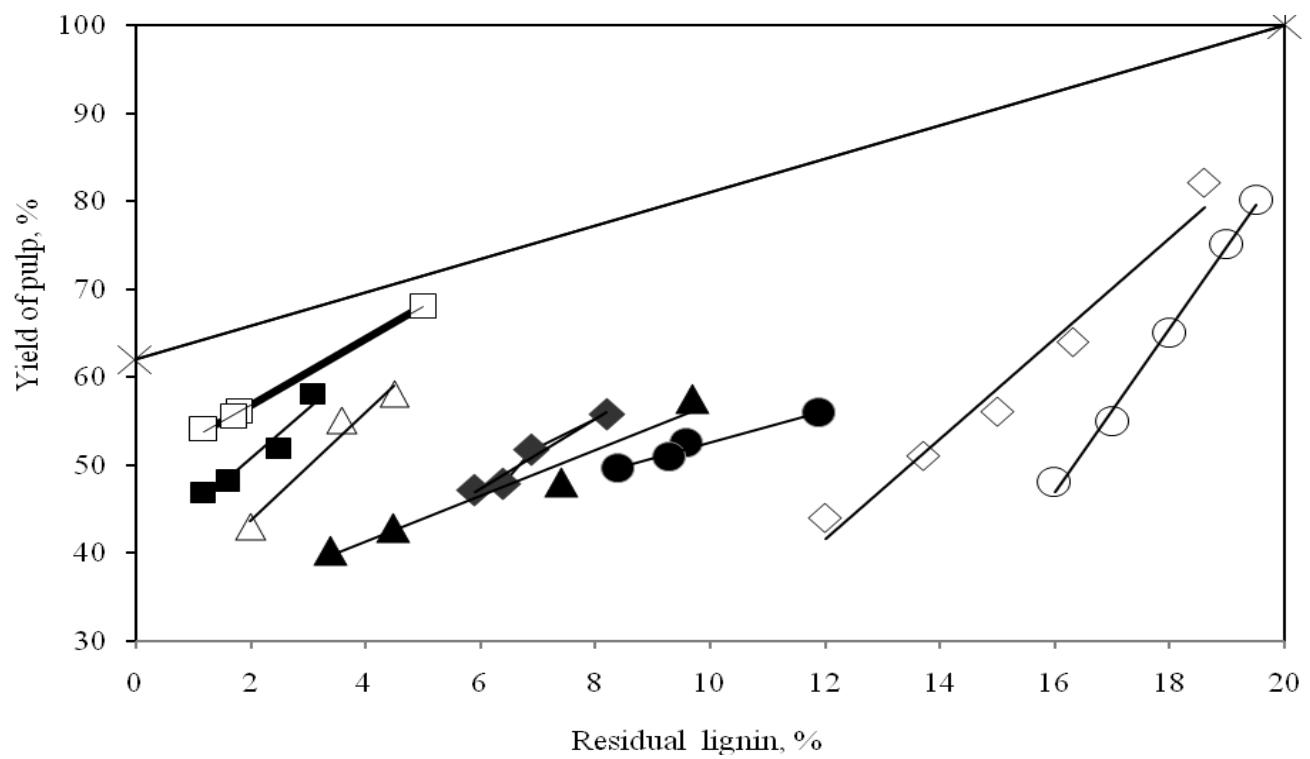

Fig. 3. The lignin-carbohydrate diagram of sunflower stalks delignification by the selected methods: N-Su $(\diamond)$, soda $(\bullet)$, peracetic $(\boldsymbol{\Lambda})$, ASAE (๘); line of "ideal delignification" (*) and for comparison - delignification of wheat straw by organosolv: $\operatorname{ASAE}(\square)$, Ester $(\diamond)$, Acetic $(\circ)$, peracetic $(\Delta)$

The dependencies shown on the diagram (Fig. 3) allowed concluding that investigated delignification methods with approaching to the line of "ideal delignification", i. e. with the increased efficiency of obtaining pulp from sunflower stalks, can be located in following sequence:

$$
\text { Soda - peracetic - N-Su - ASAE. }
$$

In order to compare dependencies of yield from residual lignin content in wheat straw pulp obtained by
ASAE, peracetic, ester $\left(\mathrm{CH}_{3} \mathrm{COOH}: \mathrm{CH}_{3} \mathrm{COOC}_{2} \mathrm{H}_{5}: \mathrm{H}_{2} \mathrm{O}=\right.$ $=33: 33: 33$ v. \%) and acetic $\left(\mathrm{CH}_{3} \mathrm{COOH}: \mathrm{H}_{2} \mathrm{O}=75: 25\right.$ v. \%) methods were shown in the Fig. 3. As it is seen in the Fig. 3, ester and acetic methods are_significantly inferior to ASAE and peracetic methods by their efficiency removal lignin from plant raw material (Fig. 3). That is why they were not used for obtaining pulps from sunflower stalks. It can be concluded from Fig. 3 that ASAE method is the most efficient among the studied 
methods and the pulp is more effectively obtained from wheat straw than from the sunflower stalks, as yield of wheat straw pulp is higher at the same residual lignin content.

The obtained dependence (1) is confirmed by comparison of delignification degree (DD) values calculated for investigated delignification methods by the following equation [30]:

$$
D D=100-\frac{Y \cdot C}{A}, \%
$$

where $A$ - original lignin content in plant, $\% ; Y$ - yield of plant residue, $\%$; $C$-residual lignin content in pulp, $\%$.

The dependencies of delignification degree on cooking time for different delignification methods of sunflower stalks are shown on Fig. 4.

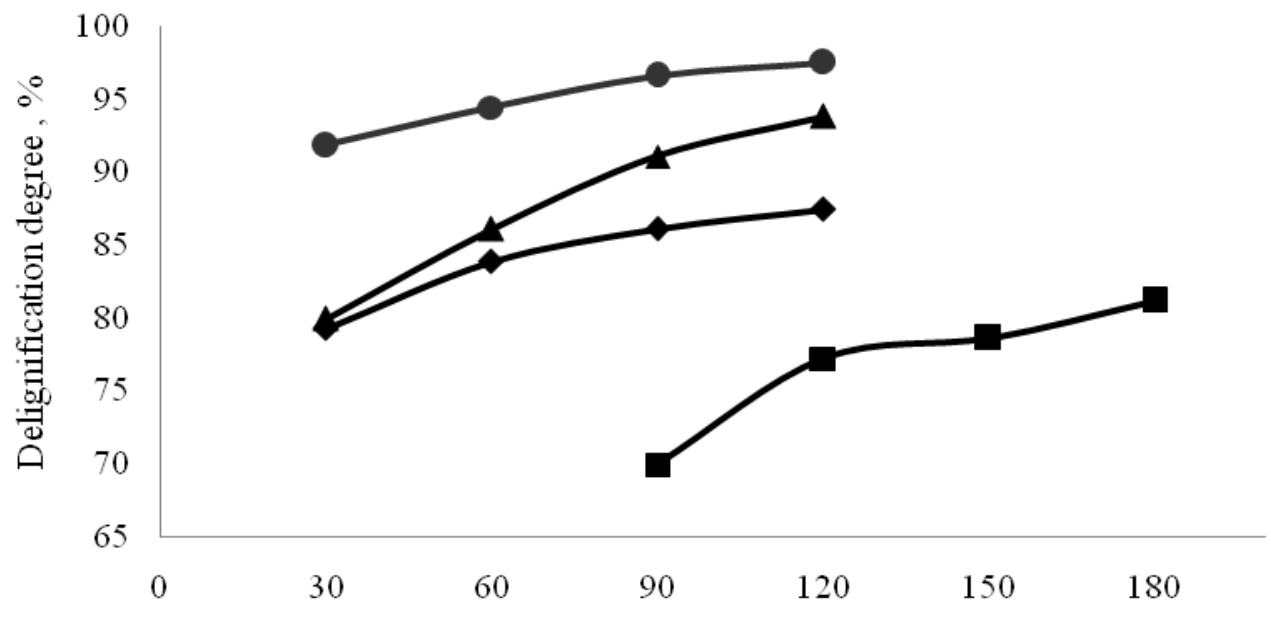

Cooking time, min

Fig. 4. Dependencies of delignification degree on cooking time of sunflower stalks delignification by different methods: $\operatorname{ASAE}(\bullet)$, peracetic $(\boldsymbol{\Delta}), \mathrm{N}-\mathrm{Su}(\bullet)$ and soda $(\boldsymbol{\bullet})$

According to obtained dependencies, increasing of cooking time increases delignification degree for all studied methods of delignification raw material, which is consistent with the known concepts of cooking processes theory. It should be noted that alkaline sulphiteanthraquinone-ethanol method is characterized by the highest indices of lignin removal from sunflower stalks and confirms the location of the studied delignification methods of sunflower stalks to obtain sequence (1).

\section{Conclusions}

The procedure of holocellulose content determination in non-wood plant raw materials was developed. For the minimization of environmental pollution by harmful chemicals and hydrolytic polysaccharides destruction of non-wood plant raw material the treatment by solution of $10 \%$ peracetic acid at a temperature of $90{ }^{\circ} \mathrm{C}$ for 30 minutes was recommended. Holocellulose content in non-wood plant material for construction of "ideal delignification" line on lignin-carbon diagram was used. The new more simple methodology of lignin-carbohydrate diagram construction was proposed. Dependencies of yields pulp on residual lignin for studied methods of delignification sunflower stalks, as it approaches to the line of "ideal delignification", are located in the following sequence: soda - peracetic - neutral-sulphite - alkaline sulphite-anthraquinone-ethanol. Dependencies of strength properties of obtained pulps and delignification degrees studied delignification methods of sunflower stalks on cooking time was confirmed obtaining sequence.

It can be concluded from proposed lignincarbohydrate diagram that delignification of wheat straw is more efficient than from the sunflower stalks at same cooking condition because yield of wheat straw pulp is higher at the same residual lignin content. Proposed lignin-carbohydrate diagram can be used for comparison as different delignification methods as for one plant raw material, as for different plant raw materials by one delignification method.

Based on the comparative results obtained in this work it can be concluded that sunflower stalks can be a potential source of raw material for pulp and paper industry and among the studied methods ASAE method of delignification sunflower stalks is the most efficient.

\section{Acknowledgments}

The authors are grateful to the Ministry of Education and Science of Ukraine for the financial support of this work.

\section{References}

1. Atchinson, J. E. Making the right choices for successful bagasse newsprint production: Part 2 [Text] / J. E. Atchinson // TAPPI J. - 1993. - Vol. 76, Issue 1. - P. 187-198.

2. Ververis, C. Fiber dimensions, lignin and cellulose content of various plant materials and their suitability for paper production [Text] / C. Ververis, K. Georghiou, N. Christodoulakis, P. Santas, R. Santas // Industrial Crops and Products. - 2004. - Vol. 19, Issue 3. - P. 245-254. doi: 10.1016/ j.indcrop.2003.10.006

3. Leponiemi, A. Non-wood pulping possibilities - a challenge for the chemical pulping industry [Text] / A. Leponiemi // Appita Journal. - 2008. - Vol. 61, Issue 3. - P. 234-243.

4. Hunter, R. W. Nonwood plant fiber uses in papermaking [Text] / R. W. Hunter // Appita. -2010. - 56 p.

5. Berg, A. Energetic viability of wheat straw fractionation by acetosolv process [Text] / A. Berg, N. Karna, C. Fuentealba // Cellulose Chemistry and Technology. - 2014. - Vol. 48, Issue 9-10. - P. 787-792. - Available at: http://www.cellulosechemtechnol.ro/pdf/CCT9-10(2014)/p.787-792.pdf 
6. Rodriguez, A. Rice straw pulp obtained by using various methods [Text] / A. Rodríguez, A. Moral, L. Serrano, J. Labidi, L. Jiménez // Bioresource Technology. - 2008. Vol. 99, Issue 8. - P. 2881-2886. doi: 10.1016/j.biortech. 2007.06.003

7. Kiaei, M. Chemical composition and morphological properties of canola plant and its potential application in pulp and paper industry [Text] / M. Kiaei, S. Mahdavi, A. Kialashaki, M. Nemati, A. Samariha, A. Saghafi // Cellulose Chemistry And Technology. - 2014. - Vol. 48, Issue 1-2. P. 105-110. - Available at: http://www.cellulosechemtechnol.ro/pdf/ CCT1-2(2014)/p.105-110.pdf

8. Jimenez, L. Optimization of pulping conditions of abaca. An alternative raw material for producing cellulose pulp [Text] / L. Jiménez, E. Ramos, A. Rodríguez, M. J. De la Torre, J. L. Ferrer // Bioresource Technology. - 2005. - Vol. 96, Issue 9. - P. 977-983. doi: 10.1016/j.biortech.2004.09.016

9. Shukry, N. Some physical properties of acetosolv lignins from bagasse [Text] / N. Shukry, S. M. Fadel, F. A. Agblevor, S. F. El-Kalyoubi // Journal of Applied Polymer Science. - 2008. - Vol. 109, Issue 1. - P. 434-444. doi: 10.1002/app.28059

10. Ateş, S. Comparison of pulping and bleaching behaviors of some agricultural residues [Text] / S. Ateş, I. Deniz, H. Kirci, C. Atik, O. Okan // Turkish Journal of Agriculture and Forestry. - 2015. - Vol. 39. - P. 144-153. doi: 10.3906/ $\operatorname{tar}-1403-41$

11. El-Ghany, N. Organosolv pulping of cotton linters [Text] / N. El-Ghany // Cellulose Chemistry And Technology. 2009. - Vol. 43, Issue 9-10. - P. 419-426. - Available at: http://scholar.cu.edu.eg/?q=abdelghanyn/files/organo_solv_pub lished.pdf

12. Small, E. Hemp: A new crop with new uses for North America [Text] / E. Small, D. Marcus; J. Janick, A. Whipkey (Eds.). - Alexandria, VA: ASHS Press, 2002. P. 284-326. - Available at: https://www.hort.purdue.edu/ newcrop/ncnu02/v5-284.html

13. Mossello, A. A. A Review of Literatures Related of Using Kenaf for Pulp Production (Beating, Fractionation, and Recycled Fiber) [Text] / A. A. Mossello, J. Harun, P. M. Tahir, H. Resalati, R. Ibrahim, S. R. F. Shamsi, A. Z. Mohmamed // Modern Applied Science. - 2010. - Vol. 4, Issue 9. doi: 10.5539/ mas.v4n9p21

14. Brosse, N. Pretreatment of Miscanthus giganteus using the ethanol organosolv process for ethanol production [Text] / N. Brosse, P. Sannigrahi, A. Ragauskas // Industrial \& Engineering Chemistry Research. - 2009. - Vol. 48, Issue 18. P. 8328-8334. doi: 10.1021/ie9006672

15. Madakadze, I. C. Evaluation of pulp and paper making characteristics of elephant grass (Pennisetum purpureum Schum) and switch grass (Panicum virgatum L.) [Text] / I. Madakadze, T. Masamvu, T. Radiotis, J. Li, D. Smith // Afr. J. Environ. Sci. Technol. - 2010. - Vol. 4, Issue 7. - P. 465-470.

16. Potucek, F. Rapeseed straw as a possible source of non-wood fibre materials [Text] / F. Potucek, M. Milichovsky // Cellulose Chemistry And Technology. - 2011. - Vol. 45, Issue 1-2. - P. 23-28. - Available at: http://www.cellulosechemtechnol.ro/ pdf/CCT1-2(2011)/p.23-28.pdf

17. Bidlack, J. E. Stern's Introductory Plant Biology [Text] / J. Bidlack, S. Jansky. - New York: McGraw-Hill Companies, 2011. - P. 140.

18. USDA. 2014. Crop Production Summary [Text]. USDA: National Agricultural Statistics Service, 2015. - 99 p. Available at: http://www.usda.gov/nass/PUBS/TODAYRPT/ cropan15.pdf

19. Smook, G. A. Handbook for pulp and paper technologists [Text] / G. Smook. - Vancouver: Angus Wilde Publications, 1997.
20. Gonzalez, M. Effect of organosolv and soda pulping processes on the metals content of non-woody pulps [Text] / M. Gonzalez, L. Canton, A. Rodriguez, J. Labidi // Bioresource Technology. - 2008. - Vol. 99, Issue 14. - P. 6621-6625. doi: 10.1016/j.biortech.2007.12.038

21. Akgul, M. Alkaline-ethanol pulping of cotton stalks [Text] / M. Akgul, A. Tozluoglu // Scientific Research and Essays. - 2010. - Vol. 5, Issue 10. - P. 1068-1074. - Available at: http://www.academicjournals.org/article/article1380624186_ Akgul\%20and\%20Tozluoglu.pdf

22. Saberikhan, E. Organosolv pulping of wheat straw by glycerol [Text] / E. Saberikhan, J. Rovshandeh, P. RezayatiCharani // Cellulose Chemistry And Technology. - 2011. Vol. 45, Issue 1-2. - P. 67-75. - Available at: http://www. cellulosechemtechnol.ro/pdf/CCT1-2(2011)/p.67-75.pdf

23. Lopez, F. Soda pulping of sunflower stalks. Influence of process variables on the resulting pulp [Text] / F. Lopez, M. Eugenio, M. Diaz, J. Nacimiento, M. Garcia, L. Jimenez // Journal of Industrial and Engineering Chemistry. -2005 . - Vol. 11, Issue 3. - P. 387-394.

24. Akgul, M. A comparison of soda and soda-AQ pulps from cotton stalks [Text] / M. Akgul, A. Tozluoglu // African Journal of Biotechnology. - 2009. - Vol. 8, Issue 22. P. 6127-6133.

25. Dixit, A. K. Efficient depithing of bagasse - a step towards sustained availability of raw material for paper industry to produce high quality paper [Text] / A. Dixit, V. Thakur, R. Jain, R. Mathur // IPPTA J. - 2010. - Vol. 22, Issue 1. P. 163-166.

26. Enayati, A. Papermaking potential of canola stalks [Text] / A. Enayati, Y. Hamzeh, S. Mirshokraie, M. Molaii // BioResources. - 2009. - Vol. 4, Issue 1. - P. 245-256.

27. TAPPI Test Methods [Text]. - Atlanta, Georgia: Tappi Press, 2004.

28. Barbash, V. Pulp obtaining from corn stalks [Text] / V. Barbash, I. Trembus, J. Nagorna // Chemistry\&Chemical Technology. - 2012. - Vol. 6, Issue 1. - P. 83-87.

29. Barbash, V. Peracetic acid pulp from annual plants [Text] / V. Barbash, V. Poyda, I. Deykun // Cellulose Chem. Technol. - 2011. - Vol. 45, Issue 9-10. - P. 613-618.

30. Barbash, V. Ammonia-sulfite-ethanol pulp from wheat straw [Text] / V. Barbash, I. Trembus, V. Shevchenko // Cellulose Chem. Technol. - 2014. - Vol. 48, Issue 3-4. P. 345-353.

\section{References}

1. Atchinson, J. E. (1993). Making the right choices for successful bagasse newsprint production: Part 2. TAPPI J., 76 (1), 187-198.

2. Ververis, C., Georghiou, K., Christodoulakis, N., Santas, P., Santas, R. (2004). Fiber dimensions, lignin and cellulose content of various plant materials and their suitability for paper production. Industrial Crops and Products, 19 (3), 245254. doi: $10.1016 /$ j.indcrop.2003.10.006

3. Leponiemi, A. (2008). Non-wood pulping possibilities - a challenge for the chemical pulping industry. Appita Journal, 61 (3), 234-243.

4. Hunter, R. W. (2010). Nonwood plant fiber uses in papermaking. Appita, 56.

5. Berg, A., Karna, N., Fuentealba, C. (2014). Energetic viability of wheat straw fractionation by acetosolv process. Cellulose Chemistry and Technology, 48 (9-10), 787-792. Available at: http://www.cellulosechemtechnol.ro/pdf/CCT910(2014)/p.787-792.pdf

6. Rodriguez, A., Moral, A., Serrano, L., Labidi, J., Jiménez, L. (2008). Rice straw pulp obtained by using various methods. Bioresource Technology, 99 (8), 2881-2886. doi: 10.1016/j.biortech.2007.06.003 
7. Kiaei, M., Mahdavi, S., Kialashaki, A., Nemati, M., Samariha, A., Saghafi, A. (2014). Chemical composition and morphological properties of canola plant and its potential application in pulp and paper industry. Cellulose Chemistry And Technology, 48 (1-2), 105-110. Available at: http://www.cellulosechemtechnol.ro/pdf/CCT1-2(2014)/p.105-110.pdf

8. Jimenez, L., Ramos, E., Rodríguez, A., De la Torre, M. J., Ferrer, J. L. (2005). Optimization of pulping conditions of abaca. An alternative raw material for producing cellulose pulp. Bioresource Technology, 96 (9), 977-983. doi: 10.1016/j.biortech.2004.09.016

9. Shukry, N., Fadel, S. M., Agblevor, F. A., ElKalyoubi, S. F. (2008). Some physical properties of acetosolv lignins from bagasse. Journal of Applied Polymer Science, 109 (1), 434-444. doi: 10.1002/app.28059

10. Ateş, S., Deniz, I., Kirci, H., Atik, C., Okan, O. (2015). Comparison of pulping and bleaching behaviors of some agricultural residues. Turkish Journal of Agriculture and Forestry, 39, 144-153. doi: 10.3906/tar-1403-41

11. El-Ghany, N. (2009). Organosolv pulping of cotton linters. Cellulose Chemistry And Technology, 43 (9-10), 419426. Available at: http://scholar.cu.edu.eg/?q=abdelghanyn/ files/organo_solv_published.pdf

12. Small, E., Marcus, D.; Janick, J., Whipkey, A. (Eds.) (2002). Hemp: A new crop with new uses for North America. Alexandria, VA: ASHS Press, 284-326. Available at: https://www.hort.purdue.edu/newcrop/ncnu02/v5-284.html

13. Mossello, A. A., Harun, J., Tahir, P. M., Resalati, H., Ibrahim, R., Shamsi, S. R. F., Mohmamed, A. Z. (2010). A Review of Literatures Related of Using Kenaf for Pulp Production (Beating, Fractionation, and Recycled Fiber). Modern Applied Science, 4 (9). doi: 10.5539/mas.v4n9p21

14. Brosse, N., Sannigrahi, P., Ragauskas, A. (2009). Pretreatment of Miscanthus giganteus using the ethanol organosolv process for ethanol production. Industrial \& Engineering Chemistry Research, 48 (18), 8328-8334. doi: 10.1021/ie9006672

15. Madakadze, I. C., Masamvu, T., Radiotis, T., Li, J., Smith, D. (2010). Evaluation of pulp and paper making characteristics of elephant grass (Pennisetum purpureum Schum) and switch grass (Panicum virgatum L.). Afr. J. Environ. Sci. Technol., 4 (7), 465-470.

16. Potucek, F., Milichovsky, M. (2011). Rapeseed straw as a possible source of non-wood fibre materials. Cellulose Chemistry And Technology, 45 (1-2), 23-28. Available at: http:// www.cellulosechemtechnol.ro/pdf/CCT1-2(2011)/p.23-28.pdf
17. Bidlack, J. E., Jansky, S. (2011). Stern's Introductory Plant Biology. New York: McGraw-Hill Companies, 140.

18. USDA. 2014. Crop Production Summary (2015). USDA: National Agricultural Statistics Service, 99. Available at: http://www.usda.gov/nass/PUBS/TODAYRPT/cropan15.pdf 19. Smook, G. A. (1997). Handbook for pulp and paper technologists. Vancouver: Angus Wilde Publications.

20. Gonzalez, M., Canton, L., Rodriguez, A., Labidi, J. (2008). Effect of organosolv and soda pulping processes on the metals content of non-woody pulps. Bioresource Technology, 99 (14), 6621-6625. doi: 10.1016/j.biortech.2007.12.038

21. Akgul, M., Tozluoglu, A. (2010). Alkaline-ethanol pulping of cotton stalks. Scientific Research and Essays, 5 (10), 1068-1074. Available at: http://www.academicjournals.org/ article/article1380624186_Akgul\%20and\%20Tozluoglu.pdf

22. Saberikhan, E., Rovshandeh, J., Rezayati-Charani, P. (2011). Organosolv pulping of wheat straw by glycerol. Cellulose Chemistry And Technology, 45 (1-2), 67-75. Available at: http://www.cellulosechemtechnol.ro/pdf/CCT1-2(2011)/ p.67-75.pdf

23. Lopez, F., Eugenio, M., Diaz, M., Nacimiento, J., Garcia, M., Jimenez, L. (2005). Soda pulping of sunflower stalks. Influence of process variables on the resulting pulp. Journal of Industrial and Engineering Chemistry, 11 (3), 387-394.

24. Akgul, M., Tozluoglu, A. (2009). A comparison of soda and soda-AQ pulps from cotton stalks. African Journal of Biotechnology, 8 (22), 6127-6133.

25. Dixit, A. K., Thakur, V., Jain, R., Mathur, R. (2010). Efficient depithing of bagasse - a step towards sustained availability of raw material for paper industry to produce high quality paper. IPPTA J., 22 (1), 163-166.

26. Enayati, A., Hamzeh, Y., Mirshokraie, S., Molaii, M. (2009). Papermaking potential of canola stalks. BioResources, 4 (1), 245-256. Tappi Press.

27. TAPPI Test Methods (2004). Atlanta, Georgia:

28. Barbash, V., Trembus, I., Nagorna, J. (2012). Pulp obtaining from corn stalks. Chemistry\&Chemical Technology, $6(1), 83-87$.

29. Barbash, V., Poyda, V., Deykun, I. (2011). Peracetic acid pulp from annual plants. Cellulose Chem. Technol., 45 (9-10), 613-618.

30. Barbash, V., Trembus, I., Shevchenko, V. (2014). Ammonia-sulfite-ethanol pulp from wheat straw. Cellulose Chem. Technol., 48 (3-4), 345-353.

Рекомендовано до публікачії д-р техн. наук, професор Гомеля М. Д. Дата надходження рукопису 17.02.2016

Valerii Barbash, PhD, Associate Professor, Department of Ecology and technology of plant polymers, National Technical University of Ukraine «Kyiv Polytechnic Institute», Peremohy ave., 37, Kyiv, Ukraine, 03056

Irina Trembus, PhD, Associate Professor, Department of Ecology and technology of plant polymers, National Technical University of Ukraine «Kyiv Polytechnic Institute», Peremohy ave., 37, Kyiv, Ukraine, 03056 E-mail: lanos0790@yandex.ru

Sergey Alushkin, Department of Ecology and technology of plant polymers, National Technical University of Ukraine «Kyiv Polytechnic Institute», Peremohy ave., 37, Kyiv, Ukraine, 03056

Olga Yashchenko, Postgraduate student, Department of Ecology and technology of plant polymers, National Technical University of Ukraine «Kyiv Polytechnic Institute», Peremohy ave., 37, Kyiv, Ukraine, 03056 